\title{
LA QUIMERA DEL FETICHE FENICIO ARQUITECTURAS DE LO COLOSAL Y EXTRAVAGANTE
}

\author{
Antonio Fernández Alba \\ Doctor Arquitecto. Académico de la Lengua y de Bellas Artes \\ ASTRAGALO, 20 (2015) \\ Attribution-NonCommercial-ShareAlike - CC BY-NC-SA \\ Artículo, ISSN 2469-0503 \\ https://dx.doi.org/10.12795/astragalo.2015.i20.02
}

En la Europa de hoy que con tanta zozobra trata de equilibrar mercados, esa figura de retórica económica con la que el último rasgo del capitalismo globalizado bautiza la balanza de sus intereses, después de un siglo azaroso marcado por tanto drama y desacreditadas catástrofes ha levantado sobre sus ruinas traslucidas y codificadas aglomeraciones urbanas, que en sus lugares y entornos el nómada telemático que por ellos transita, no encuentra tarea artesana ni atajo tranquilo a la altura de su afán científico.

No es de extrañar por tanto, la melancolía que tales cambios de imágenes suscitan, melancolía, como pasión estética por las formas, entendida según el sentir de la tradición clásico-renacentista, como el punto de partida emocional para lograr la novedad como postulado creador en las plataformas posmodernas y así, la arquitectura ha cambiado la sabiduría de la construcción y la naturaleza de los materia- les, en abstractos símbolos y perfiles de la imagen que reproducen los valores supremos de los signos de tal mercado.

En el viejo arte de la arquitectura, en las fases iniciales de las vanguardias, el capitalismo industrial hacía patente sus diferencias entre lo simbólico y lo económico; en los rasgos de estos monumentos del capitalismo tardío lo simbólico es manifiesta expresión del valor absoluto del poder de los beneficios, lo colosal y extravagante, unidos en una demótica ficción y alucinación expresiva construyen sin pudor los vacíos filisteos de la nueva metrópoli ${ }^{1}$.

Es cierto, que las paginas mejor acotadas de lo que fueron objeto los análisis de la historia de la ciudad del siglo veinte, apuntaban a la necesidad de un dialogo estimulante para planificar y ordenar las variables del pensamiento científico y tecnológico, dialogo tan bien apro- 
vechado por el racionalismo arquitectónico para redactar algunos de los "formalismos utópicos" y códigos autoritarios de la función, sin admitir en tales proyectos las corrientes paralelas de la insurrección, de aquellos ciudadanos empeñados en la defensa del binomio ilustrado de la igualdad y de la libertad, que las ciudades enternecidas por las corrientes del iluminismo no habían podido encender.

En esta tensión dialéctica entre el proyecto, construcción de la metrópoli contemporánea y mercado globalizado, no se puede desligar de la nueva actitud ante la historia que plantea, sin duda, el debate de las dos morales, de acentuada evidencia en la arquitectura; moral de decadencia y moral de modernidad. La primera postula como principio, no manifiesto, la nostalgia como práctica activa y, así la traza simulada hará elocuente el trámite de la utopía ensoñada; la moral de modernidad, carece de pasado, al desconocer la acumulación del tiempo recubre los espacios urbanos de una actualidad precipitada que manifiesta sin pudor, el desconocer el principio de verdad de la forma, que determina al discurso de la arquitectura de la metrópoli a sobrevivir en un simulacro perpetuo, ejemplos no faltan. Todo esto sucede, no conviene olvidarlo, una vez que los epígonos de las vanguardias han hecho evidentes los axiomas del crepúsculo.

No estará mal, recordar algunas acotaciones epistolares ya lejanas, entre un crítico como Herbert Read y el sociólogo Karl Mannheim, quien se mostraba tan escéptico ante el anarquismo urbano como del autoritarismo del planificador; señalaba Mannheim (1954): Aunque no creo que el principio del anarquismo en su forma histórica funcione en una sociedad de técnicas sociales modernas, la tarea de la filosofía sigue siendo la de enseñar una y otra vez a la humanidad que los modelos de organización son múltiples y que los orgánicos no necesitan ni deben ser supeditados a una organización rígida ${ }^{2}$.

Diagnósticos no faltaron para ordenar un modelo de ciudad, ante las tenues esperanzas burguesas y las ilusiones de la razón moderna, para intentar equilibrar las aleatorias derivas de un mundo de organización burocrático-progresista de desarrollo acelerado, en apartados tan esenciales como el de las comunicaciones o los acelerados procesos de urbanización, movilidad y cambio planificado, conceptos más propicios a la hagiografía de estos parámetros por parte de los urbanistas, que a la crítica práctica y beligerante sobre la formalización de lo urbano.

La planificación de la ciudad, es cierto, que como un presupuesto ideológico de la razón política estaba arropada por la vanguardia arquitectónica, que tan singulares edificios y bellas ilustraciones dejaron en torno a la primavera de Weimar. Los aeroplanos de los dibujos de Le Corbusier volando sobre la cuadricula cartesiana de Paris de los años veinte, anunciaban ya el final de un periodo histórico que aún sustentaba sus cimientos en la argamasa de los saberes de las ciencias y las artes de la Ilustración, y los fundamentos democráticos de aquellos tiempos trataban de ser esgrafiados y dejar patente el significado de sus conquistas en el obelisco de los Rights of men.

Pero el siglo veintiuno aún no ha podido recoger en la penumbra de aquellos ideales del progreso y la razón los valores morales y éticos el proyecto de la ciudad, que trata ahora 
de prolongarse desde las aulas y mercados en filigranas y requiebros formales de ilusorias deconstrucciones, políticas, económicas y culturales, de la nueva-vieja academia posmoderna ${ }^{3}$.

Los gritos amargos sobre la ciudad precedente nos confirman en múltiples ocasiones, que la evolución de la nueva metrópoli discurre por los parámetros que marcan las derivadas económicas y, construye sus espacios y edificios de forma simbólica, de manera que la espacialidad metropolitana se transforma en objeto mercancía sometido a las leyes del mercado, así, instituciones y edificios, energía y transporte, vivienda y familia, propiedad y alquileres, ciencia y cultura configuran unos tiempos de transformaciones permanentes de cambio y escasas certezas. Lo humano acorralado por la veracidad de lo real, administrando lo global como verdad incierta en ese magma candente que destilan las sociedades del consumo acelerado.

La metrópoli del segundo milenio de naturaleza tecnocientífica viene estructurada por el nuevo capitalismo de mercado, arropado como se sabe, por transformaciones y adaptaciones del capitalismo monopolista y las alternativas, que a veces sugiere y pacta con el capitalismo de estado. Estas relaciones integran o atomizan, no solo las estructuras de empresa sino que corrigen los costes sociales, estatus de clase, políticos y económicos, la propia naturaleza del proyecto, de manera que controlan la nueva morfología de la ciudad, arquitecturas, ingenierías de servicios, las formas de vida cotidiana y, sobre manera, las nuevas relaciones de producción, movilidad, información, y crecimiento. Productividad capitalista y potencia de la tecnociencia, son dos apartados esenciales que requieren una fundamentación radical, ideológica, critica y estética del proyecto arquitectónico junto a los macroproyectos de la ingeniería civil actuales. Una profunda revisión por lo que respecta a sus colosales desarrollos físicos y a sus valencias destructivas sobre el medio natural.

Ante tal deriva cabe preguntarse: quién construye la ciudad hoy y que proyecto organiza el modelo de estos artefactos metropolitanos. El desarrollo de la ciudad industrial verificado durante el siglo veinte junto a sus métodos de propaganda ideológica, enterraron hace bastante tiempo, aquel espejismo de racionalidad y progreso, que prometían una reconquista de la ciudad. Convencidos, que la razón no siempre es garantía de libertades y que el progreso no conduce ciertamente a la felicidad. Patente quedo durante el siglo veinte, que las utopías sociales cuando se formulan en el espacio real, concluyen en algún modelo de gulag, y, los mitos sociales tan alentados por las conquistas del progreso, a veces, pueden concluir en desolación datada como barbarie.

No será necesario recurrir a bibliografía especializada para encontrar en España, la crónica enfatizada de tantos proyectos de arquitectura e ingeniería que se levantan como grades parques temáticos de la ficción urbana, bajo seudónimos de la Ciudad de las ciencias o Ciudad de las culturas y de las Artes, devorando los viejos valles en los acantilados del finisterre gallego o consolidando viejos cauces fluviales mediante proyectos de soliloquios enardecidos, como procesos de innovación técnica y arquitectónica, sin control, en los presupuestos fraudulentos, en sus diseños y sobre los efectos secundarios del medio natural ${ }^{4}$. 
Esta cosmogonía de artefactos que constituyen estos híper-mercados de la evasión donde la arquitectura representa una elocuente fractura entre la persona y el espacio urbano construido. Son proyectos que, en definitiva, están más atentos a los efectos de ilusión e innovación que a su finalidad del habitar, responden en el ocaso del canon de la modernidad, a escenarios de la derrota arquitectónica que se formalizan desde la condición posmoderna y, que consagra a la arquitectura como un fetiche de la imagen más que como un recinto antropológico de los lugares de la nueva metrópoli.

Abolición por tanto de la identidad, que se plantea en una doble valoración, como individuo y como grupo, como valoración estética subjetiva y como percepción estética colectiva, en definitiva, fractura entre el objeto y su función. La negación de la identidad en el medio físico metropolitano reclama la necesidad critica de incorporar en el nuevo proyecto; la historia individual, llena de silencios en un dialogo con los artefactos técnicos de la arquitectura o la ingeniería y los medios informatizados que pueblan los conglomerados de las nuevas urbes.

Vivimos una civilización donde el sistema cultural se ha transformado en un fin en sí mismo, que nos lleva a producir artefactos como verdaderas maquinas psíquicas de suelos, paredes y techos. Diseñados por los dioses del instante como los romanos denominaban algunas de sus divinidades, manifestando su presencia, para hacer evidente los valores que encerraba la percepción visual de sus escenarios. Como no interrogamos ante estas arquitecturas del éxtasis en el plenilunio de la crisis del espacio público.

¿Qué arquitectura será posible en estas nacientes metrópolis de las postrimerías icónicas, donde la hipertrofia de medios técnicos coloniza todo vínculo de este humanismo fragmentado?

En la calle solo quedan los expedientes monotécnicos del caminante solitario, según la melancólica cita de Walter Benjamin. Expedientes y signos de arquitecturas diseñadas con la pretensión de ser arquetipos de convulsión y belleza, en la realidad, tangentes solo con la contingencia del consumo; esa necesidad fingida de propiedad donde también el edificio se ha vaciado como objeto de su verdadera finalidad y función. Equilibrio difícil para el ciudadano (nómada telemático), en tiempos de credo materialista y triunfo de los intereses de mercado, que tiene que contemplar cómo se transforman los espacios de la ciudad en una guía de transeúntes, como si se tratara de narrar el epistolario codificado del adiós, donde apenas se puede asistir al desahucio del yo, entre tan inmisericordes arquitecturas de lo colosal ${ }^{5}$.

Sodoma y Sion se contaminan, confunden y desaparecen cuando se captura la cultura y sobre la política de su crecimiento natural, se acumula sobre ellas, de la misma manera que en nuestras ciudades contemporáneas, una mezcla difusa y altanera de alegorías que se sobrepone a la insostenible hostilidad espacial de sus recintos. Olvidando que la construcción de la ciudad es, tiempo y espacio que se hacen habitables. El modelo de proyecto futuro requiere de un equilibrio entre la presencia estructural de sus técnicas, y el diagnostico de las ausencias culturales de su tiempo.

Las arquitecturas que protagonizan los lugares de la metrópoli contemporánea, responden a una condición mercantil, donde el edificio como objeto-fetiche, giro visual de la arquitec- 
tura acentuado en la postmodernidad, ha de rentabilizar la imagen; sus diseñadores adquieren el rango de sofistas del espacio urbano, versados en la retórica de las formas, con dominio del lenguaje del ordenador, que permite expresar de manera análoga la belleza o banalidad de un espacio, su función, es vender la imagen que produce. Arquitecturas de franquicias destinadas a consumir de manera eficiente, los ritos de la forma simulada, los espacios del destiempo, de los símbolos de estratificación banal de los objetos; herederos al fin del mito burgués del significado del estatus, son edificios sublimados en un sucedáneo estético del arcaico fetiche fenicio que de nuevo pretende marginar a la arquitectura del espacio político en la ciudad.

Los espacios dominantes construidos por la industria de la cultura planificadora de la metrópoli vienen manipulados por las oligarquías de la estética de evasión, hábilmente soportada por ambiciosas tecnologías estructurales para la comercialización visual de lo contemporáneo y, que van configurando la nueva cartografía metropolitana, bien definida por los mapas que registran los modos de producción, aquellos que canalizan las redes de intercambio $y$ negocios, esa guía sentimental, quimera de consumo y ocio.

La utopía de los fines que animaban las imágenes de las vanguardias del siglo precedente, han claudicado ante la utopía de los medios que impone el capitalismo de mercado globalizado. Nada más prioritario que el beligerante discurso público sobre como levantar nuestros lugares de convivencia global y ambiental bajo un triple proyecto, critico, político y existencial.

\section{NOTAS}

1 Los modelos económicos que operan en los territorios de la ciudad, vacían el espacio urbano de las cualidades del habitar y es reemplazado por un espacio abstracto por donde circulan los diferentes servicios públicos diseñados a veces por proyectos de una ruda economía espacial.

2 Read, H., Anarchy and order, Faber y Faber, Londres, 1954, pag. 14

3 El eclecticismo histórico del posmodernismo ha servido de coartada para fundir en un relato de mercado, el ámbito de lo simbólico y lo productivo, falseando hasta la caricatura los espacios y formas de la arquitectura; bajo la cínica ideología de la complicidad, como señala T. Eagleton; con alguna de las realidades políticas más aceptables de la actual sociedad burguesa... Fraudes financieros, blanqueos, encubrimientos y medias verdades, no son ya necesidades esporádicas y lamentables sino necesidades continua y estructuralmente esenciales de la mismas. Terry Eagleton, La estética como ideología, pag. 461, Trotta, Madrid, 2006.

$4 \mathrm{El}$ proyecto de la arquitectura encajado en las sociedades de mercado, ha sido devaluado en sus valores morales, éticos y estéticos que promulgaban las vanguardias y la propia razón de ser edificatoria del arte y la técnica, al transformarse en mercancía, es un producto más, vaciado de moralidad, creando una espacialidad liquida, sin justificación racional alguna pero diseñado por una tecnología poderosa, racionalizada y administrada, que asumirá la facultad de fabricar el fetiche sin fisuras, entre lo económico y lo simbólico.

Con menos aceleración, algo parecido ha comenzado a penetrar en los grandes proyectos de la ingeniería de servicios donde la empresa contemporánea controla desde hace tiempo, las opciones iconoclastas que son intrínsecas al valor de cambio de la mercancía.

5 De nuevo la polis, requiere unos modelos de proyecto que permitan ordenar el pensamiento del nuevo universo de la cultura digital y la acción edificatoria que incorporen los valores éticos abandonados de la cultura constructiva, acelerando la síntesis e integración de las significativas conquistas de las arquitecturas e ingenierías en siglos tan prodigiosos, que permitan equilibrar los saberes del conocimiento y la técnica. Antes que, las fracturas actuales en universidades, escuelas y empresas, sigan aferradas en seguir coronando el arcaico mito-estilo que custodian, las Torres de Babel. 


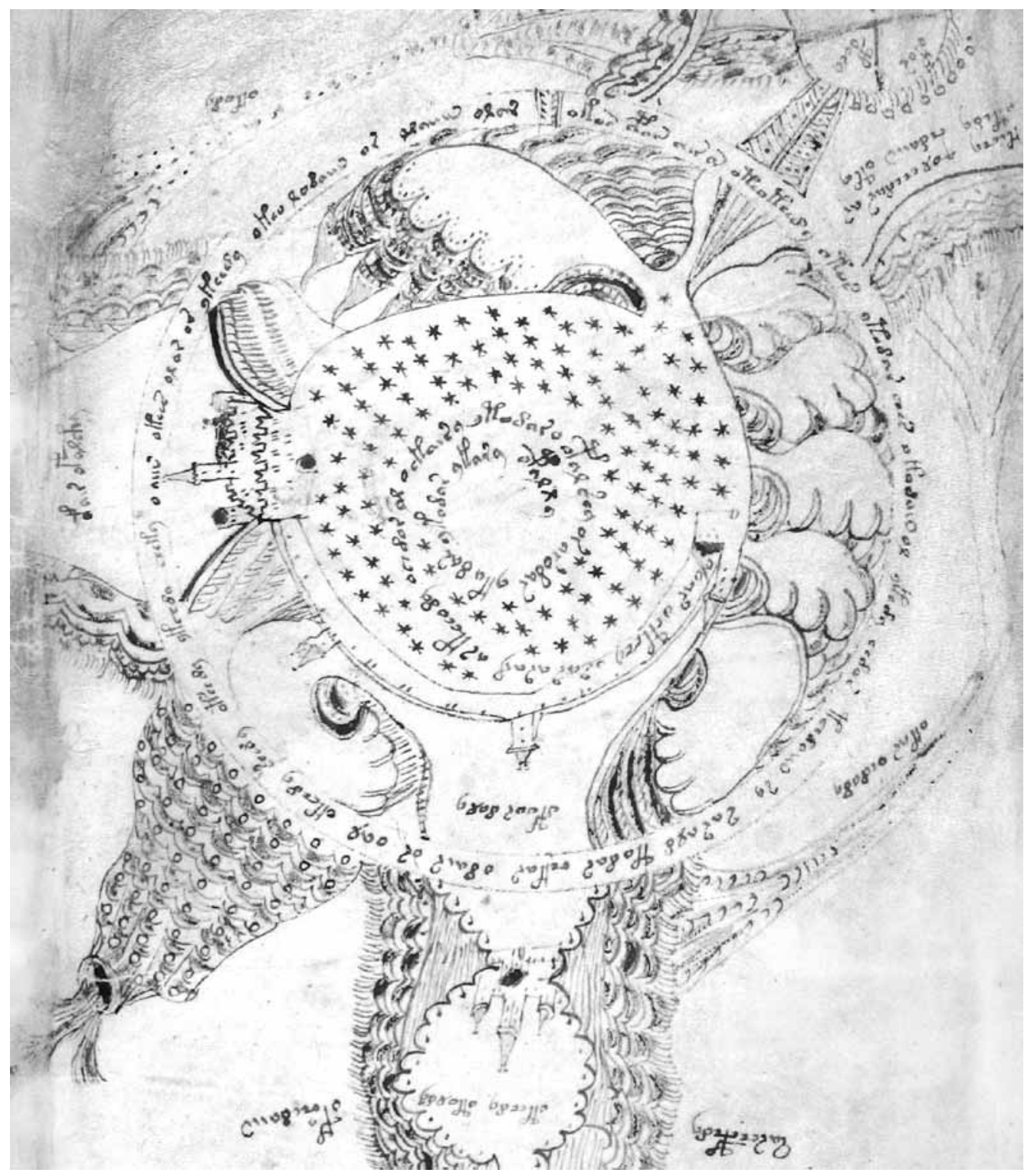

